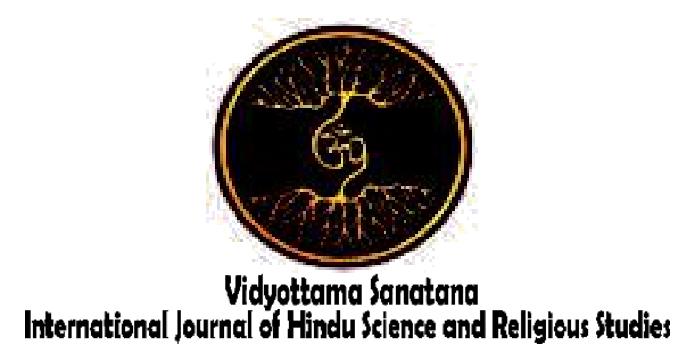

Vol. V No. 1 June 2021

\title{
THE IMPLICATION OF TIKTOK APPLICATION AS A MEDIA FOR THE DISSEMINATION OF TRI HITA KARANA'S TEACHINGS DURING THE COVID-19 PANDEMIC
}

\author{
By: \\ I Dewa Gede Darma Permana \\ Universitas Hindu Negeri I Gusti Bagus Sugriwa Denpasar \\ dewadarma75@gmail.com
}

Received: April 16, 2021

Accepted: June 30, 2021

Published: June 30, 2021

\begin{abstract}
The popularity of the TikTok application in the current era needs to be directed positively to spread the teachings of Tri Hita Karana. This is because Tri Hita Karana's teachings are able to restore the balance of the world to face the COVID-19 pandemic. Reflecting on this, researchers are interested in examining more deeply the implications of the TikTok application as a medium for spreading the teachings of Tri Hita Karana during the COVID-19 pandemic. In this study, several problem formulations were formulated, namely related to the popularity of the TikTok application, the importance of the teachings of Tri Hita Karana during the COVID-19 pandemic, and the implications of the TikTok application as a medium for spreading the teachings of Tri Hita Karana. Using this type of qualitative research, with a visual ethnographic approach, the results of this study indicate the implications of the TikTok application as a medium for disseminating the teachings of Tri Hita Karana, which have advantages in terms of making unique videos, as well as in terms of effective and efficient video promotion to provide additional insights to viewers about teachings of Tri Hita Karana as a joint force to face the COVID-19 pandemic.
\end{abstract}

Keywords: TikTok, Tri Hita Karana, The COVID-19 Pandemic 


\section{INTRODUCTION}

Change is eternal in every life. This is in line with the opinion of William Fung, one of the big businessmen from China who said the phrase "The only constant is change" (Sembel and Sugiharto, 2009: 17). Facing all the changes that occur, humans are required to always innovate. Especially in the current era known as the Millennial era, a productive era for the generation of people born in the 1980s to 2000s, bringing winds of significant life change, especially in the field of technology. This era is marked by the characteristics of the development and use of increasingly advanced technology, everything related to sophisticated machines, cellphones continue to develop until they are called smartphones, the internet is already available, making it easier for people to telecommunications anywhere and anytime with available applications (Maharani, 2019). Therefore, innovation through technology is considered effective in dealing with any changes that occur.

The one evidence of significant changes in human life has been proven since 2020 with the COVID-19 phenomenon (Corona Virus Disease-2019). This virus, which is declared a pandemic, causes social restrictions in social life, exists in the political, educational, economic fields, including in the field of religion. Even in the field of religion which is based on the noble teachings of the scriptures, all activities that usually involve large numbers of people, such as the celebration of religious holy days, must be limited to strict health protocols. This certainly makes most of the religious community inevitably obey all these rules to prevent the spread of the Corona virus.

From these social restrictions, information and communication technology media are very intensively used by the world community to overcome these problems. However, in this case, the use of technology also needs to be considered so as not to cause other problems. This is undeniable, considering the development of technology when viewed from a beneficial perspective, can be compared to a knife, which means that in addition to being positively correlated to facilitate human life, especially in terms of telecommunications, technology can also be negatively correlated with life. From excessive and unwise use, technology has begun to make people especially the younger generation easily forgets God, eliminates tolerance, hinders socialization in society because they are too busy with gadgets, thus causing a lack of sympathy and even making crime cases rampant through technological means (Faiza and Firda, 2018: 710). For this reason, humans who are given the ability to be more in the form of a natural mind (Citta) are expected to always be able to suppress the negative impact of the misuse of this technology.

Directing technology to be used in positive ways, especially innovating with creative work, can be one solution to reduce the negative impact of technology abuse. One of the directions of technology for this positive thing can be done by utilizing technology itself as a medium for the dissemination of religious teachings. This is because religious teachings are rich in moral values that are useful for directing humans to noble personalities through their thoughts, words, and deeds, including Hinduism. Through the teachings of Hinduism, humans are always led to know and take the advantage of good actions (Subha Karma) because they will produce good results while trying to avoid bad actions (Asubha Karma) because they will also produce bad results. This is according to what is contained in the Hindu Law Book, namely Manawa Dharmasastra XII. 3 which reads as follows:

\section{Çubhāçubha phalam karma manowāgdeha sambhawam, karmajā gatayo nrnam uttama dhyamāh.}

The meaning:

"Karma that is born of mind, speech, and body have good or bad results, with karma causing various states to arise in humans, whether for the highest, middle, or lowest." (Pudja and Sudharta, 1973: 718; Suwendra, 2018: 25-26).

Especially during a world condition that is still facing the current COVID-19 pandemic, 
the socialization of Hinduism through technological media needs to be intensified. Moreover, it can spread the teachings of Hinduism which can become a common force in the face of the COVID-19 pandemic.

Among the various noble teachings possessed by Hinduism in various parts of the world with their respective local wisdom, there is one of the noble teachings of Hinduism, as well as being a local genius of the island of Bali called Tri Hita Karana. Tri Hita Karana is philosophical teaching of Hinduism in Bali, Indonesia, which directs humankind to always have a happy life by establishing a harmonious relationship with God, humans, and the environment (Peters and Wardana, 2013). The teachings of Tri Hita Karana harmony, if it is known by many people, especially if it can be implemented regularly properly, of course, it can become a joint force in facing the COVID-19 pandemic. This is because one of the causes of COVID-19 comes from the imbalance or disharmony of Bhuana Agung, namely the Universe, and Bhuana Alit which is the contents of the universe, which is caused by human karma (deeds), and the environment (Adnyana, 2020; Wulandari, 2020: 284). So that in this case the community needs to know and implement the teachings of Tri Hita Karana so that the balance and harmony of life can be returned to normal. For this reason, Tri Hita Karana's teachings need to be disseminated during the current COVID-19 pandemic, especially using technological media to be able to reach many people.

However, due to the strong magnetic power of technological developments, a more creative and efficient way of spreading Hinduism was needed. A creative and efficient way that can be done is to use TikTok as an application of the technology itself, to spread the teachings of Tri Hita Karana during the current COVID-19 pandemic. The TikTok application in this case allows users to share information, including religious teachings, through short videos of 15 to 60 seconds in length with music, filters, and several other creative features. This also makes the TikTok application very popular with the Indonesian people, from teenagers, children, to the elderly (Adawiyah, 2020: 136). In fact, according to research results from Fatimah Kartini Bohang (in Dewanta, 2020: 80), the TikTok application ranks as the most downloaded application with 45.8 million downloads, beating other popular applications such as YouTube, WhatsApp, Instagram, and even Facebook. By looking at this phenomenon, researchers are interested in studying the "The Implication of TikTok Application as a Media For The Dissemination of Tri Hita Karana's Teachings during the COVID-19 Pandemic." But before that, we will discuss first the TikTok application and its popularity, then the second is about the importance of implementing the teachings of Tri Hita Karana during the COVID-19 pandemic. After knowing the two discussions, then they are connected to find out the implications of the TikTok application as a medium for spreading the teachings of Tri Hita Karana during the COVID-19 pandemic.

\section{METHOD}

This research uses qualitative research with a visual ethnographic approach, where this research uses research information sources in the form of visual data and field data with several methods, namely reflexive, collaborative and participatory. Research with a visual ethnographic approach (Pink 2009: 3) is an approach to experience, interpret, and represent the culture of society that is informed by tools and informed through disciplinary agendas and different theoretical principles. In this case the researcher examines the prevalence of making TikTok videos via smartphone devices as a modern culture. Then this modern culture is implied as a medium for spreading the teachings of Tri Hita Karana during the COVID-19 pandemic. Visual ethnography focuses more on engaging humans as image and voice recorders to analyze data in the form of audio-visual recordings.

In visual ethnography it is also stated that the researcher uses reflexivity and subjectivity approaches. Reflexivity here is useful for an ethnographer to enter into a phenomenon and influence how the observed data reality studies the general features of a modern culture. So in this case, the researcher 
tries to enter into the modern cultural phenomenon of "making TikTok videos", to find out the process of making TikTok videos, and what are the advantages that characterize the TikTok application. Then the subjectivity here leads to the ethnographer's ability to involve important things such as ethnographic knowledge, interpretation skills, and the ability to represent the data obtained, so as to produce ideas or ideas that support the research results. So in visual ethnographic research, researchers try to find data related to the importance of spreading the teachings of Tri Hita Karana during the pandemic, then develop them using the researchers' interpretations. This was done in an effort to find out the implications of the TikTok application as a medium for spreading the Tri Hita Karana Teachings during the COVID19 pandemic. Then the results of the final interpretation are presented in the 'results and discussion' section.

\section{RESULTS AND DISCUSSION}

\section{The Popularity of the TikTok Application} during the COVID-19 Pandemic

TikTok is a type of social media application or platform that is currently loved by almost all groups of children, teenagers, including parents around the world. TikTok is also one of the fastest growing social media platforms in the world. According to Fatimah Kartini Bohang's research, (in Dewanta, 2020: 80 ), since it was launched in September 2016, until the first quarter (Q1) in 2018, the TikTok application ranks as the most downloaded application with 45.8 million downloads, beating other popular applications such as YouTube, WhatsApp, Instagram, even Facebook. It is proof that, in just two years, the TikTok application has been very successful in attracting smartphone users around the world to download and use it.

TikTok as an application allows its users to create short 15-second videos with the advantages of music, filters, and several other creative features (Adawiyah, 2020: 136). Because of the advantages of the TikTok application, a world application survey institute called SensorTower shows the latest data that the TikTok application in the early period in 2021 ranks second as the most popular non-game (non-gaming) application with up to 62 million installs, only losing to the Telegram application downloaded 63 million times (CNN Indonesia, 2021). Even though if you look at the world situation from 2020 when the COVID-19 pandemic began to hit globally, applications such as Zoom, Google Meet, and other video conferencing applications, actually deserve to be in the top ranks as the most popular applications, because they are used as a medium of distance communication by involving large numbers of people by various schools and other agencies in most parts of the country.

That is a testament to the huge popularity of TikTok as a world application. Based on this information, it can be concluded that, during the COVID-19 pandemic, which undermined human life, which forced most of the world community to implement social restrictions, such as maintaining distanceand all activities carried out online. The TikTok application appears to be the closest friend of the world community to express all feelings of boredom and fatigue during the pandemic by making creative videos of 15 to 60 seconds in length which are equipped with features such as music, filters, and other special effects. This is what makes the application made by Zhang Yiming, a Chinese man and a graduate student of Software Engineer from Nankai University, China (in TribunManado.co.id, 2020), an application that is in demand by all people because of its uniqueness and advantages of features in it.

Another advantage of the TikTok application is that it does not take too long to edit or create videos. It is because the video duration is relatively short, so it can be fairly easy to use. Then, with the various features available, users of this application can freely channel their creativity to create various types of video content, be it short videos about food, trade promotions, even educational videos that are useful for others. This allows TikTok users to easily create unique videos and create interesting content as entertainment, educational channels, and other channels that are positive (Hasilohan et al., 2020: 75). The 
TikTok application is also a medium and a means of helping someone create various works to show their creativity from various fields, such as a talent for dancing, painting, cooking, etc. Besides the current state of the COVID-19 pandemic, the TikTok application can also improve the user's mood.

With the pandemic condition that has yet to show signs of disappearing, of course, fear, worry, and stress still surround the hearts of the world community seeing the death toll that continues to increase until now (Yuwono, 2020: 136). This fear causes the world community to spend more time staying at home. This condition of course makes the world community bored quickly, so one way to make the mood better is to play TikTok, whether it's just watching other people's work or making TikTok videos yourself and uploading them to social media. When it comes to physical activity, making TikTok videos is also a simple form of exercising at home. Even the movement to make TikTok videos tends to be fun to do. So in this case, making TikTok videos spurs people to be active. Seeing this case, of course, it is good for people who are lazy to exercise during the pandemic, because when playing TikTok without realizing it, the users have made movements that can burn calories in their body.

Although it has many advantages for the world community during the COVID-19 pandemic and making it a popular application, the use of the TikTok application in this case also needs to be directed in a positive direction. This is because the TikTok application can have a negative impact if it is misused. The appeal of making TikTok videos is different from the others, making TikTok application users unable to distinguish which video content is appropriate and inappropriate to upload. Many TikTok video users make videos intending to get a lot of responses from the audience, but they also need to think about the useful aspects of the TikTok videos that are made.

Users who only think about how to make TikTok videos that are good, interesting, and have a lot of response from the audience regardless of what they are showing, of course, it can create content that has a bad impact on others and themselves. This is what triggers the TikTok application to be at risk of becoming a Cyber Bullying media because uploaded videos are not suitable to watch and are the target of comments from social media observers (Damayanti and Gemiharto, 2019: 12). With the TikTok application directed to create video content that is useless or even leads to negative content, it makes users waste valuable time, so they become less productive in doing something more useful. Besides teenagers who use the TikTok application excessively, are also at risk of developing laziness for teenagers who are still in school, so they forget the time to study and ultimately affects their learning achievement. For this reason, the use of the TikTok application needs to be directed in a positive direction, to create video content that is useful for many people.

\section{The Importance of Tri Hita Karana's Teachings during the COVID-19 Pandemic}

If linked to the perspective of Hinduism that comes from the Vedic scriptures, in fact, disasters, disease outbreaks, and a life that is not conducive, such as what happened during the current COVID-19 pandemic, are characteristics of the predicted darkness of the Kali Yuga era (Peni, 2017). Even though, as a living being equipped with the Citta (mind) by God, it is fitting for humans not to be silent, let alone give up with all these conditions. Precisely with the advantages of this thought, along with the noble teachings of Hinduism that have been passed down by ancestors from hereditary, these religious teachings can be used as weapons to face all the challenges of life, one of which is the COVID-19 pandemic. From the many noble teachings of Hinduism that are spread throughout the world with various influences from local wisdom, there is a teaching that can be explored to deal with the current COVID-19 pandemic. This teaching is known as Tri Hita Karana.

Tri Hita Karana is a teaching in the form of a philosophical concept which is the way of life of the Balinese people, especially those who adhere to Hinduism. Etymologically, Tri Hita 
Karana comes from three words. The first is from the word "Tri" which means three, the second from the word "Hita" which means happiness or joy, and the third word is "Karana" which means 'cause'. So that if interpreted in general, Tri Hita Karana is three things that cause a prosperous, happy, and joyful life (Lilik and Mertayasa, 2019: 64). In realizing this happiness, the teachings of Tri Hita Karana contain three elements that build balance and harmony between humans and God which is called Parahyangan, humans and fellow humans are called Pawongan, and humans with an environment called Palemahan (Peters and Wardana, 2015). 2013). These three elements are the three parts that are bound and mutually influence one another.

By considering one of the causes of the COVID-19 pandemic which comes from an imbalance between humans as Bhuana Alit, and the universe as Bhuana Agung (Adnyana, 2020; Wulandari, 2020: 284), of course, Tri Hita Karana's teachings have a strategic position as teachings that are important and must be known by the community to balance the world situation again. With the return of world balance, the happiness of all living beings in the world can also follow. Besides that, the Corona virus can be prevented from spreading so that the world can return to normal. From this knowledge, it can be ascertained that the teachings of Tri Hita Karana can be used as a joint strength for humankind in the face of the COVID-19 pandemic.

Knowing Tri Hita Karana's teachings as a common force during the COVID-19 pandemic is indeed important, but the implementation of the Tri Hita Karana teachings is much more important in the current pandemic era. Like someone who has a sharp sword as a weapon, but doesn't know how to use it, that sword will be of no use at all and can even injure someone who tries to use it. Likewise, if the Tri Hita Karana teachings are only studied but not implemented, the Tri Hita Karana teachings will only become teachings in the scope of the theory, but its main benefits as teachings that bring balance and happiness to the world will never be obtained. For this reason, it is important to know activities that reflect the form of implementation of the teachings of Tri Hita Karana during the COVID-19 pandemic. The implementation is divided into three parts according to the number of Tri Hita Karana elements, i.e. the implementation of the Parahyangan teachings, the implementation of the Pawongan teachings, and the implementation of the Palemahan teachings. The three implementations can still be carried out, but still, adjust to the conditions during the COVID-19 pandemic.

\subsection{Implementation of Parahyangan Teachings during the COVID-19 Pandemic}

Parahyangan is teaching that emphasizes the harmonious relationship between humankind and God with His various names and manifestations, which Balinese Hindus call Ida Sang Hyang Widhi Wasa. During the COVID-19 pandemic, a harmonious relationship with God can be implemented by always offering devotion, so that with His grace, this pandemic can always be fast. Submitting devotion to God here should not be accompanied by fear, but needs to be based on sincere love and devotion. Worshiping God should not only be done when experiencing calamities like the present condition, but God must be remembered and worshiped regularly as evidence of gratitude for the gift of health and strength that is still being given so far. This is following the message contained in Bhagavad Gita IX. 14, which states the following:

Satatam kirtayatom mam, yatantas ca drsha vrtatah, namasyantas ca mam bhatya, ni tyayuktah upsate.

The meaning:

"Do it all the time to praise Me and do it endlessly. You who worship Me endlessly and with eternal devotion are close to Me." (Pudja, 2013: 231).

Then in establishing a relationship with God, also requires a sincere sense of sincerity from humankind. Don't ask Him too much, because with sincere devotion, even without being asked, all the needs of humankind are 
certainly granted. This is following the message contained in Bhagavad Gita IX. 22, which states the following:

\section{ananyāś cintayanto māán ye janāh paryupāsate, teșāin nityābhiyuktānāmín yoga-kșemaí vahāmy aham}

The meaning:

"Those who always worship Me with faithful only, without thinking about anything else, and are always full of devotion to Me. To them, I bring what they don't have, and I protect what they have." (Pudja, 2013: 236).

The implicit meaning of the verse is, when humankind has always remembered their God and sincerely devoted to God as a form of a harmonious relationship between humans and God, undoubtedly even during pandemic conditions like this, humankind who carry out such things will always be preserved and given what they need. Furthermore, in its current conditions that are mostly at home, Parahyangan teachings can be used as a momentum to get closer to Ida Sang Hyang Widhi Wasa by studying more sacred literature to fill spare time while at homeor carrying out Tapa and Samadhi to find peace with a mind centered on God and all His manifestations. Moreover, cleaning holy places such as temples is also a form of activities to implement Parahyangan teachings that can be carried out during a pandemic, especially being able to maintain cleanliness to prevent the spread of the Corona virus in these holy areas.

\subsection{Implementation of Pawongan Teachings during the COVID-19 Pandemic \\ Pawongan is teaching that emphasizes} the harmonious relationship between humans and each other. In the current era of the COVID19 pandemic, of course, the implementation of this teaching is quite different from before. In the current pandemic era, even though there are appealsto keep distance and do not make crowds, Pawongan's teachings for humans to establish a harmonious relationship with each other can still be done by always taking care and reminding fellow humans to maintain cleanliness, stay to care each other and help each other in a period.
This is difficult, whether it is assistance in the form of food or other thingsand still carrying out productive activities with the family at home only by observing the applicable health protocols. The implementation of this Pawongan teaching, we can also give an example through the behavior of the Maharaja Dasaratha described in Kakawin Ramayana sarga I on 3 (Suastika et al., 2016: 29) which reads as follows:

\section{“Gunamanta Sang Dasarata, Weruh sira ring weda bhakti ring dewa, tar malupeng pitra puja, Masih ta sireng swagotra kabeh".}

The meaning:

"Ida Sang Prabu Dasaratha is a king with good character, always remembers him of the teachings of the Veda and devotion to God, never forgets the worship of the Ancestors (Sang Hyang Pitara), and always gives happiness to all his relatives."

So the verse gives a message to humankind that, apart from establishing a harmonious relationship with God by studying the holy teachings in holy books such as the Veda, carrying out the teachings of Pawongan by establishing harmonious relationships with fellow humans also needs to be carried out. This can be realized by being devoted to parents as ancestors who deserve respect, then balanced with the attitude of helping each other to maintain happiness between relatives even during the difficult conditions of the COVID-19 pandemic.

\subsection{Implementation of Palemahan Teachings during the COVID-19 Pandemic \\ Palemahan is teaching that emphasizes} the harmonious relationship of humans with the surrounding environment and the universe and its contents. During the COVID-19 pandemic, this teaching can be implemented at any time by keeping the environment clean, caring for plants, and also feeding animals around the place of residence. This Palemahan teaching is also explained further in the book Manawa 
Dharmasastra IV.56 as a book of Hindu Law which states as follows:

\section{Napsu mutram purisam wa, sthiwanam wa samutrsjet, amedhya lipya menyadwa, lohitam wa wisaniwa}

The meaning:

"They should not urinate or defecate into the water of rivers, lakes, seas, not spit, and utter rants, nor throw dirt, garbage, blood, or anything poisonous." (Pudja and Sudharta, 2002: 227).

From the verse, it can be interpreted that, as human beings who are equipped by God with more abilities in terms of thoughts, humankind should be able to actively participate in maintaining the cleanliness of the environment by not littering or things that are not good for nature carelessly. After guarding activities, caring activities also need to be carried out such as replanting trees, especially in the home environment so that the air around the residence becomes cool, and other positive activities such as feeding pets at home. Moreover, based on the findings of neuroscience expert Francisco Varela, the activity of feeding pets is evidence of an act of compassion that causes people who carry it to have less risk of heart attacks than people who do not have pets (Prama, 2011: 78). So all of these activities are a form of implementation of Palemahan teachings during the COVID-19 pandemic and have tremendous benefits for life. This teaching is also closely related to Rta as an eternal natural law (Lestawi, 2015: 14). In simple terms, this natural law says "If humans do good to nature, then nature will take care of humans well. And vice versa if humans act arbitrarily to nature, nature will also be arbitrary to humans". For this reason, the importance here is in implementing the teachings of Palemahan, intending to live harmoniously, especially during the current COVID-19 pandemic.

\section{Implications of the TikTok Application as a Media for Spreading the Tri Hita Karana Teachings}

With the explanation from the previous sub-chapter, it can be seen that the teachings of
Tri Hita Karana, when implemented properly, can become a joint strength in facing the COVID-19 pandemic. For this reason, it is necessary to spread this teaching during the COVID-19 pandemic so that it is known and implemented by the general public. To fulfill this noble goal optimally, of course, an effective, efficient, creative, and attractive way is needed to ask the general public to be pleased to know and implement the teachings of Tri Hita Karana during the COVID-19 pandemic. With the explosion in popularity of the TikTok application during the COVID-19 pandemic, there is nothing wrong with TikTok application users, especially Hindu youths who have a creative spirit, the potential of the TikTok application can be directed more nobly to spread the teachings of Hinduism, one of which is the teachings of Tri Hita Karana is a common forcefacing the COVID-19 pandemic. Moreover, this also indirectly suppresses the negative impact of misuse of technology and directs technology, especially the TikTok application, to positive use.

In terms of basic studies, the use of the TikTok application as a medium for disseminating one of the teachings of Hinduism, i.e. Tri Hita Karana, is a form of innovation in the use of technology in the realm of education which has become commonplace in the Millennial era. This begins with the study of Finn (1960; FIP-UPI Educational Science Development Team, 2007: 178) which in their paper entitled "Technology and the Instructional Process" states that the use of technology in people's lives is similar to conditions in the realm of education. Thus, the use of technology, which in this case the TikTok application is coupled with education in the form of the Tri Hita Karana teachings, is both appropriate and natural.

Knowing the basis of this study, the current implications depend on the creative power and the role of people, especially the younger generation of Hindus who are willing to use the TikTok application to make unique and creative videos that contain the knowledge and an invitation to implement the teachings of Tri Hita Karana during the COVID-19 
pandemic. This can be started from simple things, such as making a video about the definition of Tri Hita Karana's teachings accompanied by unique dances and music, an explanation of the three elements of the Tri Hita Karana part, as well as a video explaining the forms of implementation of the Tri Hita Karana teachings during the COVID-19 pandemic. After making a simple video, the making of TikTok videos can be continued with more contextual things such as the benefits of implementing Tri Hita Karana's teachings, both for its physical benefits to prevent the spread of the Corona virus, as well as spiritual benefits as a medium for self-introspection to become a better person, all the benefits of implementing the teachings of Tri Hita Karana are useful in world balance and harmony. In a special TikTok video with music, filters, and special effects, of course, spreading the teachings of Tri Hita Karana during the COVID-19 pandemic in this way, will offer something different and have its appeal to the general public, especially the general public who watch it.

In terms of duration, videos from the TikTok application have a maximum duration of 1 minute, this is an advantage for the TikTok application as a medium for spreading Hinduism. This is because users of the TikTok application who intend to spread the teachings of Tri Hita Karana through TikTok videos, do not need to be too worried about video editing which is usually complicated, such as editing the opening or closing video. TikTok application users can make simple videos that directly target the core teachings of Tri Hita Karana. Then, if the Tri Hita Karana teachings to be conveyed are true quite a lot and require a fairly long duration of time, the video can be divided into several parts, then disseminated one by one according to the sequence. For example, video part 1 explains the teachings of Parahyangan, part 2 explains the teachings of Pawongan, etc.

Another advantage of using the TikTok application as a medium for spreading the teachings of Tri Hita Karana is in terms of video promotion. In the current Millennial era, good work including video will lose to ordinary videos with good promotions. It can be seen from the number of Hindu religious learning videos that have been scattered through Youtube, drowning and seemingly difficult for the general public to know, due to weaknesses in terms of promotion. With the high popularity of TikTok videos today, socialization videos about the teachings of Tri Hita Karana by using the TikTok application can reach other social media such as Instagram, Facebook, and others. From there, video promotion becomes easier, because on social media there is a tag and story system, which functions as a notification for other accounts to want to watch the video in question, so the promotion does not cost anything at all. Then, if the videos made are of high quality or are considered attractive by netizens, it is likely that large social media accounts with abundant followers and friends will also help in spreading and promoting the video so that the opportunity for videos to be watched by more people is very open. This is certainly a very extraordinary innovation in spreading the teachings of Tri Hita Karana, moreover, it can broaden the public's insight, especially the younger generation of Hindus who watch it, so they are pleased to implement the teachings of Tri Hita Karana as a common force in facing the COVID-19 pandemic.

From a different point of view, when a video is made using the TikTok application as an innovation to spread the teachings of Tri Hita Karana during the COVID-19 pandemic, TikTok application users who make videos can invite their other friends to work together to make videostogether or just help in promoting the TikTok video for the dissemination of the relevant Tri Hita Karana teachings. So in this case, in addition to the innovation and creativity of users who make TikTok videos on fertilizers, character education in the form of cooperation that can strengthen family values is also developed, even though during the current COVID-19 pandemic conditions that limit people from meeting in person. Added with participating in the making of TikTok videos about the teachings of Tri Hita Karana, the knowledge of the Hindus who made the videos concerned about the teachings of Tri Hita Karana is growing. So from there, it will further 
increase the sense of love and pride in the teachings of Tri Hita Karana is the noble teachings of the cause of harmony and happiness.

\section{CONCLUSION}

TikTok is a popular application that is currently loved by all groups and generations. By looking at the potential popularity of the TikTok application during the COVID-19 pandemic, it can be implicated as a medium for spreading the teachings of Tri Hita Karana. The teaching of Tri Hita Karana is positioned as noble teaching that directs humankind to establish a harmonious relationship with God (Parahyangan), fellow humans (Pawongan), and with the environment and its contents (Palemahan). This harmony needs to be established to restore balance to a world that is shaky due to the arrival of the COVID-19 pandemic. For this reason, considering the extraordinary useful aspects of the teachings of Tri Hita Karana as a collective strength in facing the COVID-19 pandemic, this teaching needs to be disseminated, especially using the TikTok application media, so that it can reach many people around the world.

Moreover, the implication of TikTok as a medium for spreading the teachings of Tri Hita Karana only depends on the creative power and role of application users, especially the younger generation of Hindus who are willing to use the TikTok application, to make TikTok videos that contain the knowledge and an invitation to implement the teachings of Tri Hita Karana during the COVID-19 pandemic. The implication also contains several advantages, i.e. in terms of making a simple video with a variety of features such as music, filters, and other special effects, as well as in terms of easy video promotion, because it can be disseminated through other social media outside the TikTok application. This is of course very effective and efficient in reaching people in the hope of increasing the understanding of the audience so that they are willing to implement these teachings as a common force in facing the COVID-19 pandemic. Then, with the various advantages that the TikTok application has in making videos, the implication is as a medium for disseminating the teachings of Tri Hita Karana, into something unique, creative, and very useful as a shield against the negative effects of technology abuse. Besides, in this case, it can increase the creativity of users and the media can strengthen family ties, during the current COVID-19 pandemic conditions which limit the public from meeting in person.

\section{REFERENCE}

Adawiyah, D. P. R. (2020). Pengaruh Penggunaan Aplikasi TikTok Terhadap Kepercayaan Diri Remaja di Kabupaten Sampang. Jurnal Komunikasi, 14(2), 135-148.

CNN Indonesia, (2021). Gusur TikTok, Telegram Jadi Aplikasi Paling Populer di Dunia. Retrieved from https://www.cnnindonesia.com/teknolo gi/20210209104423-185-604034/gusurTikTok-telegram-jadi-aplikasi-palingpopuler-di-dunia

Damayanti, T. dan Gemiharto, I. (2019). Kajian Dampak Negatif Aplikasi Berbagi Video Bagi Anak-Anak di Bawah Umur di Indonesia. Jurnal Komunikasi, 10(1), 1-15.

Dewanta, A. A. N. B. J. (2020). Pemanfaatan Aplikasi TikTok Sebagai Media Pembelajaran Bahasa Indonesia. Jurnal Pendidikan dan Pembelajaran Bahasa Indonesia, 9(2), 79-85.

Faiza, Arum dan Firda, Sabila J. (2018). Arus Metamorfosa Milenial. Kendal: Ernest CV Achmad Jaya Group.

Hasiholan et al. (2020). Pemanfaatan Media Sosial TikTok sebagai Media Kampanye Gerakan Cuci Tangan di Indonesia untuk Pencegahan Corona COVID-19. Jurnal Ilmu Komunikasi, 5(2), 70-80.

Lestawi, I Nengah. (2015). Hukum Hindu serta Perkembangannya. Surabaya: Paramita.

Lilik, \& Mertayas, I. K. (2019). Esensi Tri Hita Karana Perspektif Pendidikan Agama Hindu. Bawi Ayah: Jurnal Pendidikan Agama dan Budaya Hindu, 10(2), 60-80. 
Maharani, Aprilia. (2019). Pengembangan Literasi Di Era Milenial. Klaten: Maharani Mediatama.

Peni, G. S. (2017). Keutamaan Yajna di Jaman Kaliyuga (Perspektif Manava Dharmasastra. Belom Bahadat: Jurnal Hukum Agama Hindu, 7(1).

Peters, Jan Hendrik dan Wardana, Wisnu. (2013). Tri Hita Karana. Jakarta: PT Gramedia.

Pink, Sarah. (2009). Doing Sensory Ethnography. London: Sage.

Prama, Gede. (2011). Bali Shanti 3: Merapikan Tempat Suci dalam Diri. Surabaya: Paramita.

Pudja, G. (2013). Bhagawad Gita (Pancama Veda). Surabaya: Paramita.

Pudja, G. dan Sudharta, Tjokorda Rai. (2002). Manawa Dharmacastra (Manu Dharmasastra) atau Weda Smrti Compendium Hukum Hindu. Jakarta: CV. Felita Nursatama Lestari.

Sembel, Roy dan Sugiharto, Totok. (2009). The Art Best Win: Becoming Smarter Tougher and Wiser Investor. Jakarta: PT Alex Media Komputindo.

Suastika et al. (2016). Nilai Karakter Bangsa dalam Kakawin Ramayana dan Mahabharata di Bali. Sastra Gocara: Journal of Old Javanese Studies, 1(1), 21-41.

Suwendra, I Wayan. (2018). Mengintip Sarang Iblis Moral. Badung: Nilacakra.

Tim Pengembang Ilmu Pendidikan FIP-UPI. (2007). Ilmu \& Aplikasi Pendidikan Bagian 2: Ilmu Pendidikan Praktis. Bandung: PT Imperial Bhakti Utama.

TribunManado.co.id, (2020). Sejarah Aplikasi TikTok, Diciptakan Oleh Pria Asal China, Bermula dari Ajang Seru-seruan. Retrieved from https://manado.tribunnews.com/2020/02/ 16/sejarah-aplikasi-video-TikTok- diciptakan-oleh-pria-asal-chinabermula-dari-ajang-seru-seruan

Wulandari, I. A. G. (2020). Creating Life in New Normal Era Based on Tri Hita Karana Concept. Vidyottama Sanatana: International Journal of Hindu Science and Religious Studies, 4(2), 283-291.

Yuwono, S. D. (2020). Profil Kondisi Stres di Masa Pandemi COVID-19 sebagai Dasar Intervensi dalam Praktek Mikrokonseling. Jurnal Bimbingan dan Konseling, 5(1), 132-138. 